\section{Thorton Hogan Anderson}

Thorton Hogan Anderson, professor emeritus at the University of Maryland, died on November 9, 1997. Professor Anderson was a political theorist who specialized in the study of American and Russian political thought and the study of the founding Congresses of the United States. Professor Anderson was in good health and intellectually active to the point of his death, and had published a book in 1993 on the first Congress. Anderson's most recent book focused upon the various regional influences on the American founding and on the way that those had manifested themselves in the first Congress. At the time of his death, Anderson was at work on yet another book on the institutional development of Congress in the decade following the ratification of the Constitution.

Thorton Anderson was born and raised in Lexington, Kentucky, where he studied for the bachelor's and master's degrees at the University of Kentucky, under the tutelage of Professor Jasper Shannon in the mid- to late 1930s. Shannon later pointed Anderson towards a fellowship at the Brookings Institution, where he completed work on his master's thesis in 1939. Also with the guidance of Shannon, Anderson left Kentucky to pursue doctoral studies at the University of Wiscon$\sin$. His progress toward the doctorate was interrupted by the Second World War, but Anderson returned to Wisconsin immediately after the war and finished his degree in 1949. In the early 1950 s, Anderson served as a visiting professor at the University of California, Berkeley and taught in the University of Maryland's Paris Program; he spent the rest of his career at the University of Maryland, College Park. Anderson's books include Brooks Adams: Constructive Conservative (1951), The Development of American Political Thought (1961), Masters of Russian Marxism (1963), and Creating the Constitution (1993).
Throughout his lifetime, Anderson was deeply devoted to the scholarly enterprise and the profession of political science, attending conferences well into retirement. At the time of his death, he still received and read both the American Political Science Review and the Journal of Politics, and he still held membership in the APSA. A man ahead of his time, Anderson was particularly devoted to the teaching, mentoring, and scholarly encouragement of women. He leaves behind a wife, Mary Lou Anderson, and a former wife, Elizabeth Anderson, both of whom hold the doctorate, and a daughter, Leslie Anderson, who holds the doctorate in political science and teaches at the University of Florida. Anderson also leaves a son, Ross Anderson, who works in Washington, DC.

Leslie Anderson University of Florida

\section{James B. Christoph}

A major contributor to the study of comparative politics over the past 40 years, James Bernard Christoph, Emeritus Professor of Political Science and West European Studies at Indiana University, died May 8, 1998 , in Bloomington, Indiana, at the age of 69 after a long illness. Jim Christoph was an accomplished academic in several different fields of endeavor-research, teaching, service, and administration. Jim had a way of teaching and engaging students that was infectious, rigorous, respectful, and enticing. He awakened and nurtured interests in comparative politics in both undergraduate and graduate students. Several of them made that study the center of their academic lives and professional activities. In 21 years of the British Politics Group awarding the Samuel H. Beer Prize for the Best Ph.D. Dissertation in British Politics, Jim's students won three times, more than any other university or supervisor.

Born in Waukesha, Wisconsin,
Jim received his B.A. with Highest Honors from the University of Wisconsin in 1950, earning Phi Beta Kappa and Phi Kappa Phi honors in the process. As an undergraduate, he established a life-long rapport with Leon Epstein, then a junior faculty member at Wisconsin. $\mathrm{He}$ went on to get his M.A. and Ph.D. at the University of Minnesota (1956), with additional work at Harvard, the London School of Economics, and the Inter-University Consortium for Political Research. More than these degrees, however, Jim was a widely educated person in several fields and enjoyed teaching interdisciplinary courses, which he frequently did in the West European Studies Program. Before going to Indiana in 1967, as chair of the political science department, he rose in the ranks at Ohio State University from instructor in 1955 to administrative positions. He also served as a Fulbright-Hays Professor in the Johns Hopkins University Bologna Center.

While serving as chair at Indiana, Jim was faced with serious challenges. As on other American campuses at the time, students and faculty at Indiana demonstrated against the Vietnam War. The limits of freedom of expression were often stretched and tested. Many of the strident voices came from Jim's department. As a member of the American Association of University Professors and American Civil Liberties Union, Jim tenaciously upheld a fundamental belief in open dialogue and academic freedom. $\mathrm{He}$ took particular pride in rallying support for a graduate teaching assistant in 1969 in the name of free speech and academic freedom. This meant challenging decisions made by powerful officials at the university, a task from which many others would shrink.

Jim was active in several professional organizations. He was on the Executive Council of the American Political Science Association, was program chair for the Midwest Polit- 